\title{
Effect of Growth Regulators on Germination and Early Seedling Growth of Salt Stressed Sensitive and Tolerant Genotypes of Rice
}

\author{
D. Panda* and D. C. Ghosh
}

Institute of Agriculture, Visva-Bharati University, Sriniketan, West Bengal (731 236), India

\section{Corresponding Author}

D. Panda

e-mail: debasishpanda007@gmail.com

\author{
Article History \\ Article ID: AR1864c \\ Received in $15^{\text {th }}$ February, 2018 \\ Received in revised form $17^{\text {th }}$ March, 2018 \\ Accepted in final form 29 ${ }^{\text {th }}$ March, 2018
}

\begin{abstract}
The effect of growth regulators like Ascophyllum nodosum extract (0.1\%), Triacontanol (5 ppm) and 28-Homobrassinolide (1ppm) in ameliorating salt stress in two genotypes of rice (IR-29 and CSR-4) under three salinity levels viz. $\mathrm{S}_{0}=$ Non saline as control, $\mathrm{S}_{1}=40 \mathrm{mmol}$

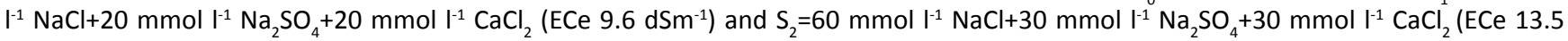
$\mathrm{dSm}^{-1}$ ) was studied on germination, seedling growth, physiological and biochemical parameters. The presowing treatment of Ascophyllum nodosum $0.1 \%$ extract and 28 -Homobrassinolide $1 \mathrm{ppm}$ were found to be beneficial in inducing salt tolerance in both sensitive (IR-29) and tolerant genotype (CSR-4). These growth regulators significantly increased the germination, seedling vigour and membrane stability index in rice seedlings under saline condition as compared to control (water soaked). Boththegrowth regulators significantly increased the activity ofantioxidant enzymeslike super oxide dismutase, glutathione reductase, catalase and peroxidase under salt stress condition as compared to that of Triacontanol $5 \mathrm{ppm}$ and water soaked seeds.
\end{abstract}

Keywords: Salt stress, Growth regulators, Ascophyllum nodosum extract, Triacontanol, 28-Homobrassinolide

\section{Introduction}

Germination and seedling development is very important for early establishment of plants under stress condition. Selecting cultivars for rapid and uniform germination under saline conditions can contribute towards early seedling establishment. Presowing priming of the rice seeds with growth regulators is known to improve the germination and seedling growth of rice. Among different abiotic stresses affecting production of rice, salinity is widely known to limit the crop growth during early seedling stage. Salt stress not only affects germination and seedling growth, but also affects other morpho-physiological and biochemical parameters of rice. The susceptibility of rice to salinity varies with different stages of growth. Rice is known to be very sensitive to salt stress during germination and early developmental stages (Heenan et al., 1988; Lutts et al., 1995). However, according to Khan et al. (1997) rice is relatively salt tolerant at germination and it becomes very sensitive at the young seedling stage (Lutts et al., 1996). Germination ability of different rice varieties varies greatly under salinity stress. The inhibitory effect of salt stress on seed germination was found to be alleviated by phytohormones such as ethylene (Chang et al., 2010), cytokinin (Khan and Huang, 1988), gibberellin acid (Kaur et al., 1998). Novel plant growth regulators like Homobrassinolides and Triacontanol are also known to modulate crop growth under various abiotic stresses(Naeem et al., 2011; Vardhini and Anjum, 2015). Presowing treatment of crop seeds with some growth regulators have been found to alleviate the effects of salt stress during seed germination (Arora et al., 2008; Sahid et al., 2011). This study was aimed to evaluate the rice genotypes for salt stress by assessing germination speed and percentage, plumule and radicle length and weight and to study the role of growth regulators in alleviation salt stress effects in rice. In this experiment attempts have been made to study the effect growth regulators such as 28-Homobrassinolide, Triacontanol and Ascophyllum nodosum extract on the germination and seedling growth of rice genotypes under salt stress.

\section{Materials and Methods}

Seeds of two rice cultivars (Oryza sativa) including IR29 and CSR-4 were used in the study were obtained from the Agricultural Research Station, Chinsura and Regional station Research station of Central Soil salinity Research Institute, Canning respectively. Before cultivation, seeds were sterilized in $1 \% \mathrm{HgCl}_{2}$ solution for three minutes, and then were rinsed with sterilized water and were air dried. The experiment was laid out in Complete Randomized 
Design (CRD) having sixteen treatment combinations, each replicated thrice. Hundred seeds of each variety in three replications were placed in Petri dishes in three replications. In each Petri dish, 2 layers of filter paper were moistened with $10 \mathrm{ml}$ of salinity treatments. The plates were placed into a BOD incubator at $28 \pm 2{ }^{\circ} \mathrm{C}$ in darkness for 10 days. The seeds were subjected to two levels of salinity viz. $\mathrm{S}_{1}=40 \mathrm{mmol} \mathrm{l}^{-1}$ $\mathrm{NaCl}+20 \mathrm{mmol} \mathrm{l}^{-1} \mathrm{Na}_{2} \mathrm{SO}_{4}+20 \mathrm{mmol}^{-1} \mathrm{CaCl}_{2}$, and $\mathrm{S}_{2}=60 \mathrm{mmol}$ $\mathrm{I}^{-1} \mathrm{NaCl}+30 \mathrm{mmol} \mathrm{l}^{-1} \mathrm{Na}_{2} \mathrm{SO}_{4}+30 \mathrm{mmol} \mathrm{l}^{-1} \mathrm{CaCl}_{2}$, respectively (Sairam et al., 2002). Four levels of growth regulators $\left(\mathrm{GR}_{0}=\right.$ No growth regulator, $\mathrm{GR}_{1}=1000 \mathrm{ppm}$ of Ascophyllum nodosum extract, $\mathrm{GR}_{2}=5 \mathrm{ppm}$ Triacontanol and $\mathrm{GR}_{3}=1 \mathrm{ppm}$ of 28-Homobrassinolide) were used to study the effect growth regulators in alleviation salt stress in rice seedlings. Hundred seeds each in three replications were sown in blotting paper substratum for germination. The substratum was kept in a BOD incubator maintained at $28 \pm 2{ }^{\circ} \mathrm{C}$ temperature for 10 days. Numbers of seedlings emerging daily were counted from the beginning of the experiment till germination was completed. The number of seeds germinated was expressed as percentage under each treatment. Radicle protrusion of $3 \mathrm{~mm}$ was scored as germination. The seedlings were evaluated as described in Seedling Evaluation Handbook (AOSA, 1991). The seedlings were harvested after ten days and used for various physiological and biochemical analysis.

Germination speed was computed by using the following formula $G S=n / d$, Where, $n$ is the number of seedlings emerging on day ' $d$ ' and $d$ is the day after sowing (ISTA, 2005). The data for the shoot and root length (mm), fresh weigh (mg) of plumule and radicle and dry weight (mg) of plumule and radicle were measured at $10^{\text {th }}$ days after germination (ISTA, 2005). Dry weights were measured after drying at $70{ }^{\circ} \mathrm{C}$ for $48 \mathrm{~h}$ into an oven (ISTA, 2005).

Vigor index of the seedlings was measured according to the methods of Abdul-Baki and Anderson (1973). Mean germination time (MGT) was calculated based on the following equation of Ellis and Roberts (1981): MGT $=\frac{\sum^{d n}}{\sum^{n}}$

Where $\mathrm{n}$ is the number of seed, which were germinated on day $D$ and $D$ is number of days counted from the beginning of germination. The germination index (GI) was calculated as described in the Association of Official Seed Analysts (AOSA, 1983) by following formula:

$\mathrm{Gl}=\frac{\text { No. of germinated seeds }}{\text { Days of first count }}+---+\frac{\text { No. germinated seeds }}{\text { Days of final count }}$

The time to $50 \%$ germination $\left(\mathrm{T}_{50}\right)$ was calculated according to the following formula of Coolbear et al. (1984) modified by Farooq et al. (2005): $\mathrm{T}_{50}=t i+\frac{\{(\underline{N} / 2)-n i\}(t j-t i)}{n j-n i}$,

Where $\mathrm{N}$ is the final number of germination and $\mathrm{ni}, \mathrm{nj}$ cumulative number of seeds germinated by adjacent counts at times ti and tj when $n i<N / 2<n j$.

Chlorophyll content of leaves was measured adopting the method of Hiscox and Israelstam (1979), using Dimethyl sulfoxide (DMSO) and was determined by using the formula given by Arnon (1949). Leaf relative water content (RLWC) estimation was determined by using the methods of Weatherley (1950). Membrane stability index (MSI) was determined by using the methods of Sairam et al. (2002). The analysis of variance of the data and the comparison of the means on the base of the least significant difference (LSD) were carried out, using MSTATC software.

\section{Results and Discussion}

The effect of salt stress on germination and seedling growth parameters of rice are shown in Table 1. Salinity treatments decreased the germination percent, seedling dry weight, shoot and root length, vigour index, germination speed and germination energy significantly over control.Salt stress induced physiological drought restricted water and nutrient uptake and retarded the seedling growth as reflected by low germination percent, seedling dry weight, shoot and root length, vigour index, germination speed and germination energy. The results are in conformity with the findings of Kandil et al. (2012). Among the three salinity levels $\left(\mathrm{S}_{0}, \mathrm{~S}_{1}\right.$ and $S_{2}$ ), $S_{2}$ recorded the lowest germination as compared to that of other levels and non saline control $\left(S_{0}\right)$ recorded the highest germination percent, seedling dry weight, shoot and root length, vigour index, germination speed and germination energy. CSR-4 recorded significantly higher germination percent than IR-29.

The growth regulatorslike Ascophyllum nodosum $0.1 \%$ extract, Triacontanol $5 \mathrm{ppm}$ and 28-Homobrassinolide 1 ppm had significant effect on the germination, vigour index and seedling growth of rice under salt stress condition (Table 1, Figure 1 and 2). Ascophyllum nodosum extract $(0.1 \%)$ recorded the highest germination and seedling growth followed by 28 -Homobrassinolide $1 \mathrm{ppm}$. Rayorath et al. (2008) also observedhigher germination and seedling vigor of barley seedlings by the exogenousapplication of Ascophyllum nodosum extract. Theenhanced germination and seedling vigor in barley might be attributed to the organic components of $A$. nodosum extract which induce amylase activity independent of $\mathrm{GA}_{3}$ and might act in concert with GA-dependent amylase production leading. They noticed that $A$. nodosum extracts modulated the concentration and localization of auxins which could account for the enhanced plant growth.

The salinity treatments decreased the osmotic potential (OP), RLWC and MSI significantly over control. Among three salinity levels $\left(S_{0}, S_{1}\right.$ and $\left.S_{2}\right)$, high salinity $\left(S_{2}\right)$ recorded lower OP, RLWC and MSI than those of other salinity levels. Higher salinity resulted in lower uptake of water and dehydration of plant tissue due to the physiological drought imposed by salt stress. Salt stress also caused membrane injury and leakage of ions which reduced the stability of cell membranes. High salinity increased uptake of sodium and chloride ions, leading to decrease in osmotic potential in plant tissues (Kwon et al., 


\begin{tabular}{|c|c|c|c|c|c|c|c|}
\hline Treatments & $\begin{array}{c}\text { Germination } \\
(\%)\end{array}$ & SG & GE & $\begin{array}{l}\text { Seedling dry wt. } \\
\text { (mg) }\end{array}$ & $\begin{array}{l}\text { Shoot length } \\
(\mathrm{cm})\end{array}$ & $\begin{array}{l}\text { Root length } \\
\text { (cm) }\end{array}$ & VI \\
\hline \multicolumn{8}{|l|}{ Salinity level } \\
\hline $\mathrm{S}_{0}$ & 94.3 & 20.7 & 68.8 & 24.6 & 9.4 & 9.2 & 176.1 \\
\hline $\mathrm{S}_{1}$ & 76.8 & 15.7 & 51.9 & 19.0 & 6.6 & 5.3 & 93.9 \\
\hline $\mathrm{S}_{2}$ & 52.2 & 9.5 & 12.1 & 13.5 & 3.5 & 2.7 & 35.7 \\
\hline SEm \pm & 0.50 & 0.21 & 0.42 & 0.17 & 0.12 & 0.10 & 1.16 \\
\hline$C D(p=0.05)$ & 1.4 & 0.6 & 1.2 & 0.5 & 0.3 & 0.3 & 3.3 \\
\hline \multicolumn{8}{|l|}{ Genotypes } \\
\hline IR 29 & 68.0 & 13.9 & 40.3 & 17.5 & 5.6 & 4.6 & 81.7 \\
\hline CSR-4 & 80.8 & 16.7 & 48.2 & 20.5 & 7.4 & 6.9 & 122.2 \\
\hline SEm \pm & 0.41 & 0.17 & 0.34 & 0.14 & 0.10 & 0.08 & 0.95 \\
\hline$C D(p=0.05)$ & 1.2 & 0.5 & 1.0 & 0.4 & 0.3 & 0.2 & 2.7 \\
\hline \multicolumn{8}{|c|}{ Growth regulators } \\
\hline $\mathrm{GR}_{0}$ & 70.4 & 14.0 & 42.6 & 18.1 & 5.8 & 5.1 & 87.3 \\
\hline $\mathrm{GR}_{1}$ & 78.7 & 16.5 & 46.1 & 20.0 & 7.2 & 6.5 & 118.9 \\
\hline $\mathrm{GR}_{2}$ & 71.1 & 14.8 & 43.4 & 18.6 & 6.2 & 5.4 & 92.3 \\
\hline $\mathrm{GR}_{3}$ & 77.4 & 15.8 & 45.0 & 19.5 & 6.9 & 6.0 & 109.2 \\
\hline SEm \pm & 0.58 & 0.24 & 0.49 & 0.20 & 0.14 & 0.12 & 1.34 \\
\hline $\mathrm{CD}(p=0.05)$ & 1.6 & 0.7 & 1.4 & 0.6 & 0.4 & 0.3 & 3.8 \\
\hline CV (\%) & 3.3 & 6.7 & 4.7 & 4.4 & 9.1 & 8.5 & 5.6 \\
\hline
\end{tabular}

SG: Speed of germination; GE: Germination energy; VI: Vigour index; $\mathrm{GR}_{0}$ : water soaked seeds; GR: Ascophyllum nodosum extract; $\mathrm{GR}_{2}$ : Triacontanol, $\mathrm{GR}_{3}$ : 28-Homobrassinolide

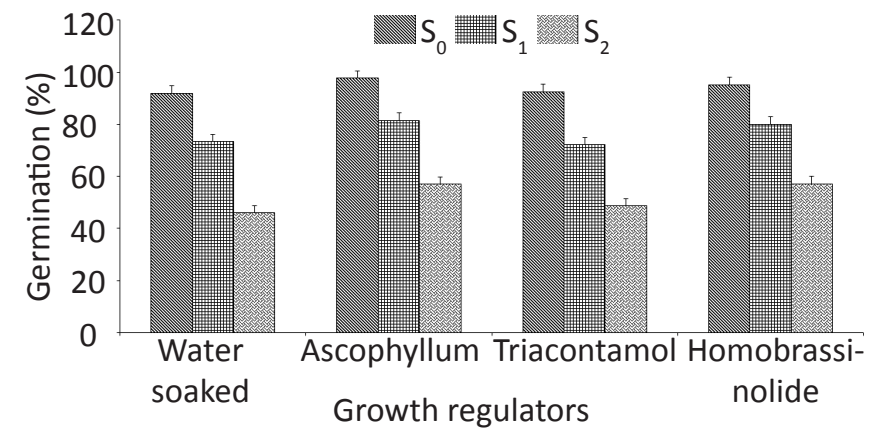

Figure 1: Interaction effect of growth regulator and salt stress on germination of rice seeds

2001). The results clearly indicated the detrimental effect of salinity on OP, RLWC and MSI in rice seedling. Similar decline in RLWC and MSI in wheat seedlings due to salt stress was also noticed by Sairam et al. (2002). CSR-4 recorded significantly higher (lower negative value) OP, RLWC and MSI as compared to that of IR-29 under salt stress condition.

Presowing treatment of growth regulatorshad significant effect on OP, RLWC and MSI of rice seedlings. Among different growth regulators, Ascophyllum nodosum $0.1 \%$ extract recorded the highest OP, RLWC and MSI closely followed by

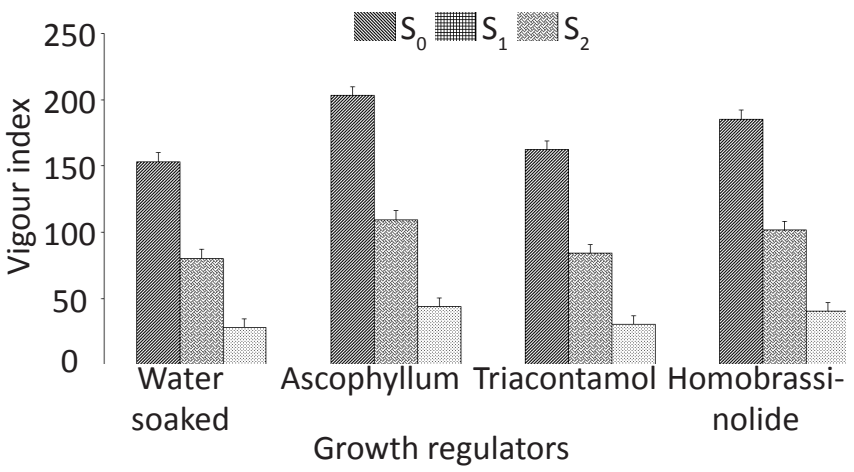

Figure 2: Interaction effect of growth regulator and salt stress on vigour index of rice seedlings

that of 28-Homobrassinolide (1 ppm). Ascophyllum nodosum $0.1 \%$ extract and 28 -Homobrassinolide $1 \mathrm{ppm}$ treatments increased the RWLC and MSI over those of Triacontanol 5 ppm and water soaked seeds. Both the treatments resulted in significantly higher MSI under salt stress condition $\left(\mathrm{S}_{1}\right.$ and $\mathrm{S}_{2}$ ) as compared to that of water soaked seeds (Figure 3 ). The results clearly showed the positive effect of Ascophyllum nodosum extract and 28-Homobrassinolide on the osmotic potential in rice seedlings. Brassinosteroids have been 


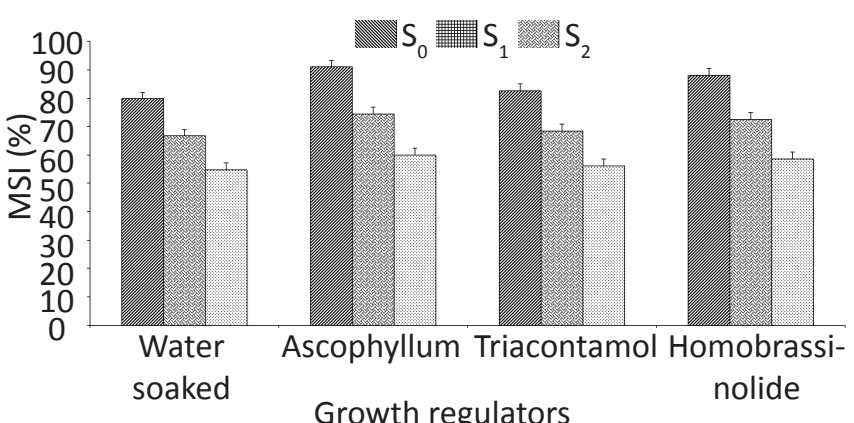

Figure 3: Interaction effect of salt stress and growth regulator on membrane stability index of rice seedlings

reported to induce abiotic stress tolerance in plants through their role in osmotic adjustment (Wang and Zeng, 1993). The growth regulators like Ascophyllum nodosum extract and 28-Homobrassinolide help the plant withstand salt stress by maintaining water balance in plant tissues. The results indicated the positive and favourable effect of Ascophyllum nodosum extract and 28-Homobrassinolide on the RLWC and MSI of rice seedlings. Sea-weed extracts of Ascophyllum nodosumwas known to alleviate the harmful effect of salinity or stress through enhancing leaf water status possibly by reducing uptake of $\mathrm{Na}$ and $\mathrm{Cl}$ ions (Nabati et al., 1994). Houimli et al. (2010) noticed that application of 24-epibrassinolide reduced the leakage of ions and improved membrane stability in pepper plants. Hayat et al. (2010) also obtained higher MSI and leaf water potential $(\psi)$ of Vigna radiata by 28 -Homobrassinolide treatment. Ascophyllum nodosum extract and 28-Homobrassinolide resulted in significantly higher MSI under both levels of salt stress $\left(\mathrm{S}_{1}\right.$ and $\left.\mathrm{S}_{2}\right)$ as compared to that of water soaked seeds. Ascophyllum nodosum extract recorded the highest MSI of rice seedlings and was closely followed by that of 28-Homobrassinolide; whereas, water soaked seeds recorded the lowest MSI under both levels of salinity. The results indicated that Ascophyllum nodosum 0.1\% extract and 28 -Homobrassinolide $1 \mathrm{ppm}$ increased the MSI of rice seedlings under salt stress condition. The Ascophyllum nodosum extracts is known to contain betaine compounds like gamma-amino butyric acid betaine, 6-aminovaleric acid betaine and glycine betaine which helps in stability of plasma membranes (Mancuso et al., 2006). Membrane stability and osmotic adjustment are two mechanisms through which Brassinosteroids are known to enhance abiotic stress tolerance in plants (Wang and Zeng, 1993).

The effect of salt stress and growth regulators on chlorophyll content, osmotic potential, relative leaf water content and membrane stability index are presented in Table 2. The salinity stress decreased chlorophyll $a$, chlorophyll b and total chlorophyll content in leaves significantly over control. Among three levels of salinity, high salinity $\left(\mathrm{S}_{2}\right)$ recorded the lowest chlorophyll content; whereas, non-saline control $\left(\mathrm{S}_{0}\right)$ recorded the highest chlorophyll content. Higher salinity
Table 2: Effect of salt stress and growth regulator on physiological parameters and chlorophyll content in germinating seedlings of rice genotypes

\begin{tabular}{|c|c|c|c|c|c|c|}
\hline \multirow[t]{2}{*}{$\begin{array}{l}\text { Treat- } \\
\text { ments }\end{array}$} & \multirow{2}{*}{$\begin{array}{c}\text { Osmotic } \\
\text { poten- } \\
\text { tial } \\
(-\mathrm{MPa})\end{array}$} & \multirow[t]{2}{*}{$\begin{array}{l}\text { RLWC } \\
(\%)\end{array}$} & \multirow[t]{2}{*}{$\begin{array}{l}\text { MSI } \\
(\%)\end{array}$} & \multicolumn{3}{|c|}{$\begin{array}{c}\text { Chlorophyll } \\
\text { content(mg/g) }\end{array}$} \\
\hline & & & & $\mathrm{Chl} \mathrm{a}$ & $\mathrm{Chl} \mathrm{b}$ & $\begin{array}{c}\text { Total } \\
\text { Chl }\end{array}$ \\
\hline \multicolumn{7}{|c|}{ Salinity level } \\
\hline $\mathrm{S}_{0}$ & 0.46 & 87.4 & 85.3 & 1.250 & 0.524 & 1.774 \\
\hline $\mathrm{S}_{1}$ & 0.65 & 73.0 & 70.4 & 1.114 & 0.449 & 1.562 \\
\hline $\mathrm{S}_{2}$ & 0.84 & 59.4 & 57.4 & 1.033 & 0.398 & 1.430 \\
\hline SEm \pm & 0.007 & 0.50 & 0.43 & 0.015 & 0.010 & 0.023 \\
\hline $\begin{array}{l}C D \\
(p=0.05)\end{array}$ & 0.02 & 1.4 & 1.2 & 0.043 & 0.028 & 0.065 \\
\hline \multicolumn{7}{|c|}{ Genotypes } \\
\hline IR 29 & 0.69 & 70.2 & 66.4 & 1.064 & 0.429 & 1.492 \\
\hline CSR-4 & 0.61 & 76.4 & 75.7 & 1.200 & 0.485 & 1.685 \\
\hline SEm \pm & 0.006 & 0.40 & 0.35 & 0.012 & 0.008 & 0.019 \\
\hline $\begin{array}{l}C D \\
(p=0.05)\end{array}$ & 0.02 & 1.1 & 1.0 & 0.035 & 0.023 & 0.053 \\
\hline \multicolumn{7}{|c|}{ Growth regulators } \\
\hline $\mathrm{GR}_{0}$ & 0.72 & 69.6 & 67.0 & 1.051 & 0.400 & 1.451 \\
\hline $\mathrm{GR}_{1}$ & 0.59 & 77.1 & 75.1 & 1.207 & 0.512 & 1.718 \\
\hline $\mathrm{GR}_{2}$ & 0.67 & 71.7 & 69.1 & 1.095 & 0.437 & 1.532 \\
\hline $\mathrm{GR}_{3}$ & 0.62 & 74.7 & 73.0 & 1.176 & 0.479 & 1.654 \\
\hline SEm \pm & 0.008 & 0.57 & 0.50 & 0.018 & 0.012 & 0.026 \\
\hline $\begin{array}{l}C D \\
(p=0.05)\end{array}$ & 0.02 & 1.6 & 1.4 & 0.050 & 0.033 & 0.075 \\
\hline CV (\%) & 5.3 & 3.3 & 3.0 & 6.6 & 10.7 & 7.0 \\
\hline
\end{tabular}

RLWC: Relative leaf water content; MSI: Membrane stability index; Chl a-Chlorophyll a, Chl b- Chlorophyll b ; Total Chl- Total chlorophyll; $\mathrm{GR}_{0}$ : water soaked seeds, $\mathrm{GR}_{1}$ : Ascophyllum nodosum extract, $\mathrm{GR}_{2}$ : Triacontanol; $\mathrm{GR}_{3}$ : 28-Homobrassinolide

reduced the uptake of different mineral nutrients especially nitrogen, which retarded the chlorophyll biosynthesis in shoots of rice seedlings. Panda and Khan (2003) also observed decline in chlorophyll content of rice genotypes under salt stress condition. Between the genotypes, CSR-4 recorded significantly higher chlorophyll content than that of IR-29. The result corroborates the findings of Alamgir et al. (1999); Sairam et al. (2002) who observed variation in chlorophyll content between sensitive and tolerant genotypes of rice and wheat respectively.

Ascophyllum nodosum extract (0.1\%)and 8-Homobrassinolide (1 ppm) treatments also recorded higher chlorophyll content than that of control. Among the growth regulators, 
Ascophyllumnodosum $0.1 \%$ extract and 28 -Homobrassinolide $1 \mathrm{ppm}$ treatments recorded higher chlorophyll content than those of Triacontanol $5 \mathrm{ppm}$ and water soaked seeds. The growth regulators like Ascophyllum nodosum extract and 28-Homobrassinolide help the plant withstand salt stress by stabilizing chloroplast membranes. Ascophyllum nodosum extract recorded the highest total chlorophyll content of leaves followed by that of 28-Homobrassinolide; whereas, water soaked seeds recorded the lowest total chlorophyll content under both high and low levels of salt stress $\left(\mathrm{S}_{1}\right.$ and $\mathrm{S}_{2}$ ). Blunden et al. (1997) reported that application of low concentration of Ascophyllum nodosum extract enhanced chlorophyll content in the leaves of tomato plants. They opined that increase in chlorophyll content was due to reduction in chlorophyll degradation, which might be caused in part by betaines in the seaweed extract. Houimli et al. (2010) also noticed the positive effect of 24-epibrassinolide on chlorophyll content of pepper plants. The higher total chlorophyll content suggests a possible role of these growth regulators in alleviation of salt stress by enhancing the rate of photosynthesis.

The effect of salt stress and growth regulators on the activity of antioxidative enzymes are presented in Table 3. The salinity treatments increased the activity of antioxidant enzymes like super oxide dismutase (SOD, EC 1.15.1.1), glutathione reductase (GR, EC 1.6.4.2), catalase (CAT, EC 1.11.1.6) and peroxidase (POD, EC 1.6.6.1) significantly over control. Among three levels of salinity, high salinity $\left(S_{2}\right)$ recorded the highest SOD, GR, CAT and POD activity; whereas, nonsaline control $\left(S_{0}\right)$ pots recorded the lowest activity of these enzymes. High salinity increased oxidative stress leading to production of antioxidative enzymes like super oxide dismutase, glutathione reductase, catalase and peroxidase to scavenge the reactive oxygen species in leaf cells. The results clearly showed the incremental effect of high salinity on the activity of the antioxidative enzymes in rice seedlings. The results are in conformity with the findings of Moradi and Ismail (2007), who observed increase in activities of enzymes involved in the reactive oxygen scavenging system in both sensitive and tolerant rice genotypes under saline condition. Similar effect of salt stress on the activities of antioxidant enzymes like SOD, CAT and GR was also observed by Sairam et al. (2002) in wheat and Kim et al. (2005) in barley. CSR4 showed significantly higher activity of the above enzymes under salt stress situation as compared to that of IR-29.

Ascophyllum nodosum extract (0.1\%) and 28Homobrassinolide (1 ppm) treatments recorded significantly higher super oxide dismutase (SOD, EC 1.15.1.1), glutathione reductase (GR, EC 1.6.4.2), catalase (CAT, EC 1.11.1.6) and peroxidase (POD, EC 1.6.6.1) activities than those of Triacontanol (5 ppm) and water soaked seeds. The results clearly showed the positive effect of Ascophyllum nodosum extract and 28-Homobrassinolide on stimulation of the super oxide dismutase, glutathione reductase, catalase and
Table 3: Effect of salt stress and growth regulator on the activity of super oxide dismutase (SOD), glutathione reductase (GR), catalase (CAT) and peroxidase (POD) in seedlings of rice genotypes

\begin{tabular}{|c|c|c|c|c|}
\hline $\begin{array}{l}\text { Treat- } \\
\text { ments }\end{array}$ & $\begin{array}{c}\text { SOD (U mg } \\
\text { protein } \\
\left.\min ^{-1}\right)\end{array}$ & $\begin{array}{c}\mathrm{GR}(\mathrm{U} \mathrm{mg} \\
\text { protein }^{-1} \\
\left.\min ^{-1}\right)\end{array}$ & $\begin{array}{l}\text { CAT (U } \\
\text { mg } \\
\text { protein-1 }^{-1} \\
\min ^{-1} \text { ) }\end{array}$ & $\begin{array}{c}\text { POD } \\
(\mathrm{U} \mathrm{mg} \\
\text { protein }^{-1} \\
\left.\mathrm{~min}^{-1}\right)\end{array}$ \\
\hline \multicolumn{5}{|c|}{ Salinity level } \\
\hline $\mathrm{S}_{0}$ & 0.46 & 87.4 & 85.3 & 1.250 \\
\hline $\mathrm{S}_{1}$ & 0.65 & 73.0 & 70.4 & 1.114 \\
\hline $\mathrm{S}_{2}$ & 0.84 & 59.4 & 57.4 & 1.033 \\
\hline SEm \pm & 0.007 & 0.50 & 0.43 & 0.015 \\
\hline $\begin{array}{l}C D \\
(p=0.05)\end{array}$ & 0.02 & 1.4 & 1.2 & 0.043 \\
\hline \multicolumn{5}{|c|}{ Genotypes } \\
\hline IR 29 & 0.69 & 70.2 & 66.4 & 1.064 \\
\hline CSR-4 & 0.61 & 76.4 & 75.7 & 1.200 \\
\hline SEm \pm & 0.006 & 0.40 & 0.35 & 0.012 \\
\hline $\begin{array}{l}C D \\
(p=0.05)\end{array}$ & 0.02 & 1.1 & 1.0 & 0.035 \\
\hline \multicolumn{5}{|c|}{ Growth regulators } \\
\hline $\mathrm{GR}_{0}$ & 0.72 & 69.6 & 67.0 & 1.051 \\
\hline $\mathrm{GR}_{1}$ & 0.59 & 77.1 & 75.1 & 1.207 \\
\hline $\mathrm{GR}_{2}$ & 0.67 & 71.7 & 69.1 & 1.095 \\
\hline $\mathrm{GR}_{3}$ & 0.62 & 74.7 & 73.0 & 1.176 \\
\hline SEm \pm & 0.008 & 0.57 & 0.50 & 0.018 \\
\hline $\begin{array}{l}C D \\
(p=0.05)\end{array}$ & 0.02 & 1.6 & 1.4 & 0.050 \\
\hline CV (\%) & 5.3 & 3.3 & 3.0 & 6.6 \\
\hline
\end{tabular}

$\mathrm{GR}_{0}$ : water soaked seeds; $\mathrm{GR}_{1}$ : Ascophyllum nodosum extract, $\mathrm{GR}_{2}$ : Triacontanol; $\mathrm{GR}_{3}$ : 28-Homobrassinolide

peroxidase activities in rice seedlings.

Ascophyllum nodosum extract and 28-Homobrassinolide treatments increased the activity of SOD, GR, CAT and POD under salt stress condition as compared to those of Triacontanol $5 \mathrm{ppm}$ and water soaked seeds (Figure 4, 5, 6 and 7). Both these growth regulators (Ascophyllum nodosum extract and 28-Homobrassinolide) help the plant withstand salt stress by their antioxidative properties. The results clearly showed the positive effect of Ascophyllum nodosum extract and 28-Homobrassinolide on stimulation of the antioxidant enzyme activity in rice seedlings. The results corroborate the findings of Fike et al. (2001). The Ascophyllum nodosum extracts is known to contain betaines like gamma-amino butyric acid betaine, 6-aminovaleric acid betaine and glycine betaine that enhanced salt tolerance 


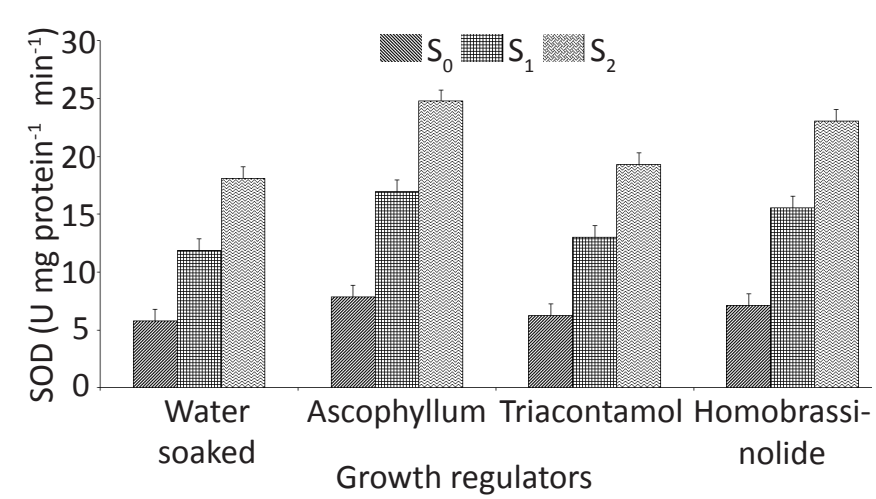

Figure 4: Interaction effect of salt stress and growth regulator on the superoxide dismutase activity of rice seedlings

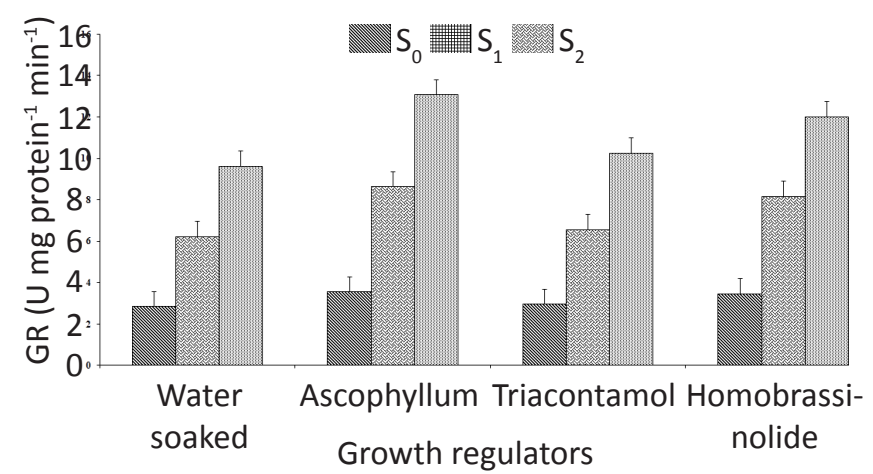

Figure 5: Interaction effect of salt stress and growth regulator on glutathione reductase activity of rice seedlings

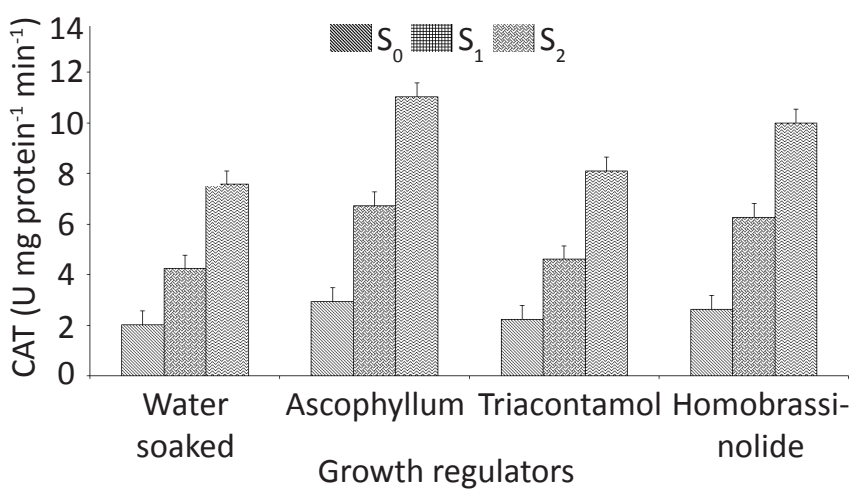

Figure 6: Interaction effect of salt stress and growth regulator on catalase activity in rice seedlings

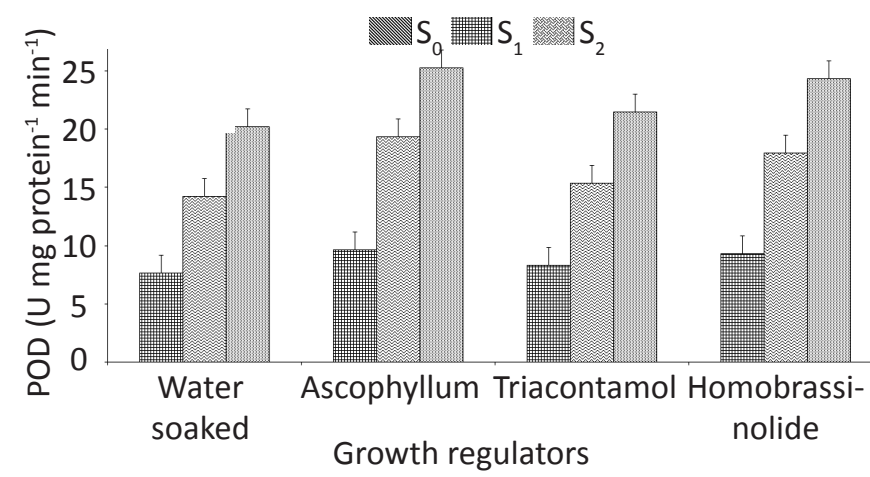

Figure 7: Effect of salt stress and growth regulators on the peroxidase activity of rice seedlings in plants when applied exogenously (Mancuso et al., 2006). Homobrassinolides are also known for their role in alleviation of salt stress by increasing the activity of anti oxidant enzymes. The results corroborate the findings of Arora et al. (2008) who found that pre-sowing treatment of 28-homobrassinolide enhanced the activities of antioxidative enzymes such as superoxide dismutase, guaiacol peroxidase, catalase, glutathione reductase and ascorbate peroxidase in Zea mays L. plants grown under salt stress condition. Higher activity of these enzymes suggests a possible role of these growth regulators in ameliorating oxidative stress generated by salt stress and enhancing the salt tolerance in plants. Sahid et al. (2011) found that presowing treatment of Epibrassinolide alleviated the effects of salt stress in pea (Pisum sativum L.) by enhancing the activities of antioxidant enzymes like superoxide dismutase (SOD), peroxidase (POD) and catalase (CAT).

\section{Conclusion}

The presowing treatment of growth regulators like Ascophyllum nodosum $0.1 \%$ extracts and 28Homobrassinolide (1 ppm) solution were found to be effective in alleviating the adverse effects of salt stress in both tolerant and sensitive genotypes of rice. Ascophyllum nodosum $0.1 \%$ extract recorded the highest germination and seedling growth followed by 28 -Homobrassinolide ( $1 \mathrm{ppm}$ ). Both the treatments resulted in significantly higher MSI, activity of antioxidative enzymes like superoxide dismutase, glutathione reductase, catalase and peroxidase under salt stress condition.

\section{References}

Abdul-Baki, A.A., Anderson, J.D., 1973. Vigour determination in soybean seed by multiple criteria. Crop Science 13, 630-633.

Alamgir, A.N.M., Ali, M.Y., 1999. Effect of salinity on leaf pigments, sugar and protein concentrations and chloroplast ATPase activity of rice (Oryza sativa L.). Bangladesh Journal of Botany 28 (2), 145-149.

Anuradha, S., Rao, S.S.R., 2001. Effect of brassinosteroids on salinity stress induced inhibition of seed germination and seedling growth of rice (Oryza sativa L.). Plant Growth Regulation 33(2), 151-153.

Arnon, D.L., 1949. A copper enzyme is isolated chloroplast polyphenol oxidase in Beta vulgaris. Plant Physiology 24, 1-15. doi: 10.1104/pp.24.1.1

Arora, N., Bhardwaj, R., Sharma, P., Arora, H.K., 2008. 28-Homobrassinolide alleviates oxidative stress in salttreated maize (Zea mays L.) plants. Brazilian Journal of Plant Physiology 20(2), 153-157.

Association of Official Seed Analysis (AOSA). 1991. Rules for testing seeds. Seed Science and Technology 12, 18-19.

Association of Official Seed Analysts, 1983. Seed vigor testing handbook. $1^{\text {st }}$ Edition, AOSA, East Lasing, 88. 
Blunden, G., Jenkins, T., Liu, Y.W., 1996. Enhanced chlorophyll levels in plants treated with seaweed extract. Journal of Applied Phycology 8, 535-543.doi: 10.1007/BF02186333

Chang, C., Wang, B., Shi, L., Li, Y., Duo, L., Zhang, W., 2010. Alleviation of salt stress-induced inhibition of seed germination in cucumber (Cucumis sativus L.) by ethylene and glutamate. Journal of Plant Physiology 167, 1152-1156.

Coolbear, P., Francis,A., Grierson, D., 1984. The effect of low temperature pre-sowing treatment on the germination performance and membrane integrity of artificially aged tomato seeds. Journal of Experimental Botany 35, 1609-17.

Ellis, R.A., Roberts, E.H., 1981. The qualification of ageing and survival in orthodox seeds. Seed Science and Technology 9, 373-409.

Farooq, M., Basra, S.M.A., Hafeez, K., Ahmad, N., 2005. Thermal hardening: a new seed vigor enhancement tool in rice. Journal of Integrative Plant Biology 47, 187-93.

Fike, J.H., Allen, V.G., Schmidt, R.E., Zhang, X., Fontenot, J.P., Bagley, C.P., Ivy, R.L., Evans, R.R., Coelho, R.W., Wester, D.B., 2001. Tasco-Forage: I. Influence of a seaweed extract on antioxidant activity in tall fescue and in ruminants. Journal of Animal Science 79, 1011-1021.

Hayat, S., Hasan, S.A., Yusuf, M., Hayat, Q., Ahmad, A., 2010. Effect of 28-homobrassinolide on photosynthesis, fluorescence and antioxidant system in the presence or absence of salinity and temperature in Vigna radiate. Environmental and Experimental Botany 69(2), 105110.

Heenan, D.P., Lewin, L.G., McCaffery, D.W., 1988. Salinity tolerance in rice varieties at different growth stages. Australian Journal of Experimental Agriculture 28, 343-349.

Hiscox, J.D., Isrealstam, G.F., 1979. A method for the extraction of chlorophyll from leaf tissue without maceration. Canadian Journal of Botany 57, 13321334. doi: 10.1139/b79-163

Houimli, S.M., Denden, M., Mouhandes, B.D., 2010. Effects of 24-epibrassinolide on growth, chlorophyll, electrolyte leakage and proline by pepper plants under $\mathrm{NaCl}$ stress. EurAsian Journal of BioSciences 4, 96-104. doi:10.5053/ejobios.2010.4.0.12

International Seed Testing Association (ISTA), 2005. International rules for seed testing, edition 2005, ISTA.

Kandil, A.A., Sharief, A.E., Nassar, E.S.E., 2012. Response of some rice (Oryza sativa L.) cultivars to germination under salinity stress. International Journal of Agriculture Science 4 (6), 272-277.

Kaur, S., Gupta, A.K., Kaur, N., 1998. Gibberellin $A_{3}$ reverses the effect of salt stress in chickpea (Cicer arietinum L.) seedlings by enhancing amylase activity and mobilization of starch in cotyledons. Plant Growth Regulation 26, 85-90.

Khan, A.A., Huang, X.L., 1988. Synergistic enhancement of ethylene production and germination with kinetin and 1-aminocyclopropane-1-carboxylic acid in lettuce seeds exposed to salinity stress. Plant Physiology 87, 847-852.

Khan, M.S.A., Hamid, A., Karim, M.A., 1997. Effect of sodium chloride on germination and seedling characters of different types of rice (Oryza sativa L.). Journal of Agronomy and Crop Science 179, 163-169.

Kim, S.Y., Lim, J., Park, M.R., Kim, Y.J., Park, T., Seo§, Y.W., Choi, K.G., Yun, S.J., 2005. Enhanced antioxidant enzymes are associated with reduced hydrogen peroxide in barley roots under saline stress. Journal of Biochemistry and Molecular Biology 38(2), 218-224.

Kwon, T., Zeng, L., Wilson, C., 2001. Changes of growth, osmotic potential and osmotic adjustment in rice under salt stress. Annual Meeting of the Soil Science Society of America held in Charlotte, NC. Oct. 20-25, 2001. (CD-ROM).

Lutts, S., Kinet, J. M., Bouharmont, J., 1995. Changes in plant response to $\mathrm{NaCl}$ during development of rice (Oryza sativusL.) varieties differing in salinity resistance. Journal of Experimental Botany 46, 1843-1852.

Lutts, S., Kinet, J.M., Bouharmont, J., 1996. NaCl-induced senescence in leaves of rice (Oryza sativa L.) varieties, differing in salinity resistance. Annals of Botany 78, 389-398.

Mancuso, S., Azzarello, E., Mugnai, S., Briand, X., 2006. Marine bioactive substances (IPA extract) improve ion fluxes and water stress tolerance in potted Vitis vinifera plants. Advances in Horticultural Science 20, 156-161.

Moradi, F., Ismail, A.M., 2007. Responses of Photosynthesis, Chlorophyll Fluorescence and ROS-Scavenging Systems to Salt Stress during Seedling and Reproductive Stages in Rice. Annals of Botany 99, 1161-1173. doi: 10.1093/ $\mathrm{aob} / \mathrm{mcm} 052$

Nabati, D.A., Schmidt, R.E., Parrish, D.J., 1994. Alleviation of salinity stress in kentucky bluegrass by plant growth regulators and iron. Crop Science 34, 198-202.

Naeem, M., Khan, M.M.A., Moinuddin, 2011. Triacontanol: a potent plant growth regulator in agriculture, Journal of Plant Interactions 7(2), 129-142.

Panda, S.K., Khan, M.H., 2003. Salt stress influences lipid peroxidation and antioxidants in the leaf of an indica rice (Oryza sativa L.). Physiology and Molecular Biology of Plants 9, 273-278.

Rayorath, P., Khan, W., Palanisamy,R., MacKinnon, S.L, Stefanova, R, Hankins, S.D., Critchley, A.T., Prithiviraj, B., 2008. Extracts of the brown seaweed ascophyllum nodosum induce gibberellic acid $\left(\mathrm{GA}_{3}\right)$-independent amylase activity in Barley. Plant Growth Regulation 27 (4), 370-379.

Sairam, R.K., Rao, K.V., Srivastava, G.C., 2002. Differential 
response of wheat genotypes to long term salinity stress in relation to oxidative stress, antioxidant activity and osmolyte concentration. Plant Science 163, 10371046. Doi: 10.1016/S0168-9452(02)00278-9.

Shahid, M.A., Pervez, M.A., Balal, R.M., Mattson, N.S., Rashid, A., Ahmad, R., Ayyub, C.M., Abbas, T., 2011. Brassinosteroid (24-epibrassinolide) enhances growth and alleviates the deleterious effects induced by salt stress in pea (Pisum sativum L.). Australian Journal of Crop Science 5(5), 500-510.

Vardhini, V.B., Rao, S.S.R., 2003. Amelioration of osmotic stress by brassinosteroids on seed germination and seedling growth of three varieties of sorghum. Plant
Growth Regulation 41, 25-31.

Vardhini, B.V., Anjum, N.A., 2015. Brassinosteroids make plant life easier under abiotic stresses mainly by modulating major components of antioxidant defense system. Frontiers in Environmental Science. Doi.org/10.3389/ fenvs.2014.00067

Wang, B., Zeng, G., 1993. Effect of 24-Epibrassinolide on the resistance of rice seedlings to chilling injury. Zhiwa Shengi Xuebao 19, 53-60.

Weatherley, P.E., 1950. Studies in water relations of cotton plants I: The field measurement of water deficit in leaves. New Phytology 49, 81-87. 